\title{
ANALISIS KREDIT BERMASALAH, TINGKAT SUKU BUNGA DAN PROFITABILITAS PADA PT BANK PERKREDITAN RAKYAT (BPR) KCP LIMBANANG KABUPATEN LIMA PULUH KOTA
}

\author{
Selvi Yona Sari, SE. MM ${ }^{1)}$ Muahammad Putra Pratama ${ }^{2)}$ \\ Universitas Putra Indonesia YPTK Padang \\ 1) Email : selvi.yona@gmail.com \\ 2) Email : mputrapratama7@gmail.com
}

\begin{abstract}
Abstrak
This study aims to analyze problem loans, interest rates, and the impact on interest income in PT Bank Perkreditan Rakyat (BPR) KCP Limbanang, Lima Puluh Kota District. The research variables are Problematic Credit (x1), Interest Rate (x2), and Profitability (y). Based on the results of this study can be concluded that the level of nonperforming loans that occur at the Bank Perkreditan Rakyat (BPR) KCP Limbanang District Lima Puluh Kota from 2011-2012 the level of non-performing loans decreased compared to the previous year, it means the credit situation is getting better. The interest rate at Rural Bank of KCP Limbanang of Lima Puluh Kota District in 2011-2015 experienced fluctuations in the proof of the highest interest rate in 2011 and the lowest interest rate in 2015. Due to total assets in Rural Bank (BPR) KCP Limbanang District Lima Puluh Kota each year experienced a significant increase whereas profitability from the year 2011-2015 that experienced ups and downs of profitability, this is influenced by the rearrangement of terms and conditions of credit Rural Bank (BPR) KCP Limbanang District Fifty Cities.Finally, the authors suggest to Rural Credit Bank (BPR) Limbanang Kabupaten Lima Puluh Kota The level of nonperforming loans that occur in Rural Banks (BPR) KCP Limbanang District Lima Puluh Kota which continues to fall every year and also problem loans also below the maximum 5\% have a positive impact on the bank, as well as an achievement for the bank as it can minimize nonperforming loans and due to improved supervision of good credit disbursement.
\end{abstract}

Keywords: Troubled Credit, Interest Rate, Profitability Revenue

\section{Pendahuluan}

Indonesia adalah salah satu negara berkembang yang perkembangan ekonominya meningkat pesat. Peningkatan ekonomi yang pesat ini diikuti dengan banyaknya peningkatan kebutuhan masyarakat di Indonesia. Di saat kebutuhan meningkat inilah bank-bank memberikan layanan dengan banyak fasilitas, seperti menerima simpanan, menerima pembayaran setoran listrik, air, telepon, pulsa, pajak, uang kuliah, dan pembayaran lainnya termasuk pemberian kredit.

Kegiatan perekonomian suatu negara tidak terlepas dari pembayaran uang, dimana industri perbankan memegang peranan yang sangat penting dan strategis dalam sistem perekonomian dan pendukung dan penggerak laju pertumbuhan ekonomi.Undang-undang Nomor 10 tahun 1998 tentang "Perbankan" menyatakan bahwa fungsi utama perbankan Indonesia adalah sebagai penghimpun dan penyalur dana masyarakat yang bertujuan menunjang pelaksanaan pembangunan nasional kearah peningkatan kesejahteraan rakyat banyak.

Sebagaimana telah diketahui sekarang ini persaingan antar bank semakin tinggi. Fenomena bermunculannya bank - bank yang semakin banyak dengan variasi kredit dan produk yang ditawarkan, mengakibatkan persaingan yang besar pula sehingga untuk mengantisipasinya pihak perbankan berlomba-lomba menyalurkan kredit sebesar mungkin dengan tetap harus menjaga 
kehati-hatian dalam melakukan kebijakan perkreditannya melalui analisa kredit maupun kebijakan dalam pengelolaanya, diantaranya dengan memberikan berbagai kemudahan dalam pemberian kredit baik dari segi jangka waktu yang relatif bervariasi, bunga yang relatif lebih kecil, maupun fasilitas yang mudah terjangkau.

Dalam penyaluran kredit, bank harus siap menghadapi risiko kredit yang menyebabkan kredit tersebut menjadi bemasalah. Risiko kredit merupakan suatu risiko akibat kegagalan atau ketidakmampuan nasabah mengembalikan jumlah pinjaman yang diperoleh dari bank beserta bunganya sesuai dengan jangka waktu yang telah ditentukan. Kredit bermasalah merupakan situasi dimana persetujuan pengembalian kredit mengalami resiko kegagalan. Kredit bermasalah atau Non Performing Loan (NPL). NPL menunjukan kemampuan manajemen bank dalam mengelola kredit bermasalah yang diberikan oleh bank, sehingga semakin tinggi NPL maka akan semakin buruk kualitas kredit bank yang menyebabkan jumlah kredit bermasalah semakin besar.

Dapat diidentifikasi jika penyaluran kredit meningkat dengan kredit bermasalah dapat dijaga dengan baik maka asset akan bertambah dan laba perbankan pun akan meningkat. Akan tetapi tidak selalu kredit bermasalah itu dapat dijaga dalam posisi yang sama setiap periodenya. Adakalanya kredit bermasalah tersebut mengalami peningkatan setiap periodenya yang tentu saja akan sangat berpengaruh terhadap laba perbankan.

\section{Tinjauan Literature}

\subsection{Pengertian Bank}

Menurut Kasmir (2014:24) Dalam pembicaraan sehari-hari, bank dikenal sebagai lembaga keuangan yang kegiatan utamanya menerima simpanan giro, tabungan dan deposito. Kemudian bank juga dikenal sebagai tempat meminjam uang (kredit)bagi masyarakat yang membutuhkannya. Di samping itu, bank juga dikenal sebagai tempat menukar uang, memindahkan uang atau menerima segala macam bentuk pembayaran dan setoran seperti pembayaran listrik, telepon, air, pajak, uang kuliahm dan pembayaran lainnya. Dari keterangan diatas dapat disimpulkan bahwa bank merupakan perusahaan yang bergerak dalam bidang keuangan, artinya aktivitas perbankan selalu berkaitan dalam bidang keuangan.

\subsection{Pengertian Kredit Bermasalah}

Menurut Suhardjono dalam Dlaudatul (2012), Kredit bermasalah adalah suatu keadaan dimana nasabah sudah tidak sanggup membayar sebagian atau seluruh kewajibannya kepada bank seperti yang telah diperjanjikan dalam perjanjian kredit

\subsection{Pengertian Tingkat Suku Bunga Bank}

Menurut Budisantoso (2015:134) tingkat suku bunga adalah dana-dana yang telah berhasil dihimpun disalurkan dalam berbagai macam bentuk penggunaannya dana dengan tujuan dasar untuk memperoleh penerimaan. Agar penyaluran dana tersebut dapat menghasilkan keuntungan bagi bank, maka biaya yang dikeluarkan dalam penghimpunan dana harus kecil daripada penerimaan yang diperoleh dari penyaluran dana.

\subsection{Pengertian Profitabilitas}


Menurut Munawir (2012:245), profitabilitas merupakan salah satu faktor yang menarik bagi para pemegang saham karena akan memicu diperolehnya penghasilan deviden yang dibayar dari keuntungan atau laba perusahaan tersebut. Disamping itu, kenaikan laba perusahaan akan memicu kenaikan harga pasar saham dan potensi di peroleh capital gains. Manajemen juga sangat tertarik terhadap laba karena sering digunakan sebagai ukuran kinerjanya.

\section{METODOLOGI PENELITIAN \\ 3.1 Objek Penelitian}

Penelitian ini dilakukan pada perusahaan PT Bank Perkreditan Rakyat (BPR) KCP Limbanang yang beralamat Jl. Tan Malaka No.25, Nagari Limbanang Kecamatan Suliki Kabupaten Lima Puluh Kota Provinsi Sumatera Barat.

Dalam penelitian data yang diperoleh ada satu jenis data yaitu Data Kuantitatif yaitu data yang berwujud angka-angka hasil perhitungan atau pengukuran dapat diproses dan menjumlahkan atau membandingkan dengan jumlah yang diharapkan maka diperoleh kesimpulan.

Bahan-bahan dan data-data yang dikumpulkan berupa data sekunder. Data sekunder berupa data kredit, data tingkat suku bunga yang dibatasi hanya dengan 4 periode saja yaitu periode 1 bulan, 3 bulan, 6 bulan, dan 12 bulan, serta data tentang untuk mencari hasil profitabilitas pada PT. Bank Mandiri Kcp Simpang Empat Pasaman Barat.

Jenis penelitian yang digunakan oleh penulis untuk mendapatkan data-data yang dibutuhkan adalah :

Menurut Anwar Sanusi (2011:107-111) jenis penelitian dibagi menjadi :

Wawancara adalah dengan melakukan tanya jawab langsung antara peneliti dengan narasumber atau pegawai Bank tersebut

Observasi adalah merupakan cara pengumpulan data melalui proses pencatatan perilaku subjek (orang), objek (benda) atau kejadian yang sistematik tanpa adanya pertanyaan atau komunikasi dengan individu-individu yang diteliti

\subsection{Variabel Penelitian}

\section{Kredit Bermasalah}

Menurut Dendawijaya (2011:82), mengatakan bahwa kredit bermasalah merupakan kegagalan pihak debitur memenuhi kewajibannya untuk membayar angsuran (cicilan) pokok kredit beserta bunga yang telah disepakati kedua belah pihak dalam perjanjian kredit. Sedangkan menurut Siamat (2004:174) pengertian kredit bermasalah adalah sebagai berikut: "Kredit bermasalah atau problem loan dapat diartikan sebagai pinjaman yang mengalami kesulitan pelunasan akibat adanya faktor kesenjangan dan atau karena faktor eksternal diluar kemampuan debitur.

\section{Tingkat Suku Bunga}

Menurut Totok Budisantoso (2015:134) tingkat suku bunga adalah dana-dana yang telah berhasil dihimpun disalurkan dalam berbagai macam bentuk penggunaannya dana dengan tujuan dasar untuk memperoleh penerimaan. Agar penyaluran dana tersebut dapat menghasilkan keuntungan bagi bank, maka biaya yang dikeluarkan dalam penghimpunan dana harus kecil daripada penerimaan yang diperoleh dari penyaluran dana.

\section{Profitabilitas}


Menurut Munawir (2012:245), profitabilitas merupakan salah satu faktor yang menarik bagi para pemegang saham karena akan memicu diperolehnya penghasilan deviden yang dibayar dari keuntungan atau laba perusahaan tersebut. Disamping itu, kenaikan laba perusahaan akan memicu kenaikan harga pasar saham dan potensi di peroleh capital gains. Manajemen juga sangat tertarik terhadap laba karena sering digunakan sebagai ukuran kinerjanya.

\subsection{Teknik Pengujian Data}

Analisis data merupakan bagian yang amat penting dalam metode penelitian ilmiah karena dengan menggunakan analisis data, Data yang di peroleh dapat diberi arti dan makna yang berguna dalam memecahkan masalah penelitian.

\section{Analisis Deskriptif}

Dalam penelitian ini penulis menggunakan analisis deskriptif dimana data-data yang berhasil dikumpulkan diolah dan kemudian di analisis yang merupakan suatu cara atau langkah dalam mengelola data sekunder untuk memecahkan masalah penelitian. Tahap pengumpulan data yang dilakukan dalam penelitian ini adalah :

1. Mengumpulkan data-data dan informasi yang relevan yang sesuai dengan tujuan peneliti.

2. Mengelola dan menganalisis data kemudian dibandingkan dengan teori yang ada pada tinjauan pustaka sehingga didapat suatu kesimpulan terhadap penelitian yang dilakukan.

Analisis data yang di lakukan dalam penelitian ini adalah :

1. Menggambarkan secara umum perusahaan PT Bank Perkreditan Rakyat yang meliputi sejarah perusahaan, visi, misi, komitmen, tata nilai, bidang usaha, dan struktur organisasi perusahaan.

2. Menganalisis dan memahami kredit.

Analisis data bersifat induktif atau kualitatif berdasarkan fakta-fakta yang ditemukan dilapangan kemudian dikontruksikan menjadi hipotesis atau teori.

\section{Metode Kuantitatif}

Analisis data kuantitatif dimasukkan untuk memperhitungkan besarnya pengaruh secara kuantitatif dari perubahan kejadian terhadap kejadian lainnya, perubahan kejadian dapat dinyatakan dengan perubahan nilai variabel. Alat analisis yang digunakan pada metode kuantitatif adalah sebagai berikut

\section{a. Analisis Kredit Bermasalah (X1)}

Bank Indonesia menetapkan bahwa tingkat NPL yang wajar adalah $<5 \%$ dari total portofolio kreditnya. Yang termasuk kedalam NPL adalah kredit kurang lancar, kredit diragukan, dan kredit macet. Menurut Surat Edaran Bank Indonesia No.3/30/DPNP Tanggal 14 Desember 2001 dapat dihitung dengan :

$$
\text { NPL }=\frac{\text { Kredit Kurang Lancar }- \text { Kredit Diragukan }- \text { Kredit Macet }}{\text { Total Kredit yang diberikan }} \times 100
$$

\section{b. Tingkat Suku Bunga (X2)}


Adapun rumus untuk mencari suku bunga pada bank yaitu sebagai berikut :

$$
B G=\frac{\text { Bunga } x \text { Nominal Pinjaman }}{12 \text { bulan }}
$$

\section{c. Profitabilitas}

Menurut Munawir (2002: 269) Profitabilitas di ukur dengan Return On Assets (ROA) adalah merefleksikan seberapa banyak perusahaan telah memperoleh hasil atas sumber daya keuangan yang ditanamkan oleh perusahaan Rumus dasar perhitungan Return On Assets secara matematis yang menurut Syamsuddin (2004) adalah sebagai berikut:

$$
\text { Return On Assets }=\frac{\text { laba bersih }}{\text { total aktiva }} \times 100 \%
$$

\section{HASIL PENELITIAN DAN PEMBAHASAN}

\section{Perkembangan Kredit Bermasalah pada PT Bank Perkreditan Rakyat (BPR) KCP Limbanang}

Menurut Surat Edaran Bank Indonesia No.3/30/DPNP Tanggal 14 Desember 2001 dapat dihitung dengan :

$\mathrm{NPL}=\underline{\text { kredit kurang lancar }- \text { kredit diragukan }- \text { kredit macet }} \times 100 \%$

Total kredit yang diberikan

Tabel 1

Kredit Bermasalah pada Bank BPR KCP Limbanang

\begin{tabular}{|c|c|}
\hline Tahun & $\begin{array}{c}\text { Persentase } \\
\text { Kredit } \\
\text { Bermasalah \% }\end{array}$ \\
\hline 2011 & $1.60 \%$ \\
\hline 2012 & $0.48 \%$ \\
\hline 2013 & $0.70 \%$ \\
\hline 2014 & $0.90 \%$ \\
\hline 2015 & $0.61 \%$ \\
\hline
\end{tabular}

Dari hasil diatas dapat disimpulkan bahwa kredit bermasalah yang ada pada Bank Perkreditan Rakyat (BPR) KCP Limbanang mengalami kredit bermasalah yang naik turun, pada tahun 2011 kredit bermasalah sebesar $1.60 \%$ pada tahun 2012 mengalami penurunan dan jumlah kredit bermasalah sebesar $0.48 \%$, dan pada tahun 2013 dan 2014 kredit bermasalah mengalami kenaikan dan jumlah kredit bermasalah sebesar $0.70 \%$ dan $0.90 \%$ dan kembali mengalami penurunan pada tahun 2015 dan jumlah kredit bermasalah sebesar $0.61 \%$. Dapat kita ketahui bahwa kredit bermasalah yang ada pada bank tersebut mengalami penurunan yang bervariasi, untuk tahun 2012 naik dibandingkan dengan tahun sebelumnya begitu juga pada tahun 2013 kredit bermasalah mengalami kenaikan kembali dan untuk tahun 2015 Bank Perkreditan Rakyat (BPR) KCP Limbanang kredit bermasalahnya kembali turun.

Perkembangan Tingkat Suku Bunga pada PT Bank Perkreditan Rakyat (BPR) KCP Limbanang 
Tabel 2

Tingkat Suku Bunga Pertahun Pada Bank BPR KCP Limbanang

Tahun 2011-2015

\begin{tabular}{|c|c|c|}
\hline Tahun & $\begin{array}{c}\text { Tingkat Suku Bunga } \\
\text { Perbulan }\end{array}$ & $\begin{array}{c}\text { Tingkat Suku Bunga } \\
\text { Pertahun }\end{array}$ \\
\hline 2011 & $1.8 \%$ & $21.6 \%$ \\
\hline 2012 & $1.625 \%$ & $19.5 \%$ \\
\hline 2013 & $1.5 \%$ & $18 \%$ \\
\hline 2014 & $1.4 \%$ & $16.8 \%$ \\
\hline 2015 & $1.25 \%$ & $15 \%$ \\
\hline
\end{tabular}

(Sumber : Bank Perkreditan Rakyat (BPR) KCP Limbanang)

Dari tabel diatas dapat kita ketahui Tingkat Suku Bunga yang ada pada Bank Perkreditan Rakyat (BPR) KCP Limbanang yang setiap tahunnya mengalami fluktuasi, pada tahun 2011 tingkat suku bunga sebesar $21.6 \%$ dan mengalami penurunan pada tahun 2012 sehingga sebesar $19.5 \%$ dan mengalami penurunan kembali pada tahun 2013 sebesar 18\% turun kembali sebesar 16.8\% pada tahun 2014 dan pada tahun 2015 mengalami penurunan kembali pada tahun 2015 sebesar 15\%, yang mana pada tahun 2015 tingkat suku bunga mengalami penurunan yang drastis dibandingkan pada tahun sebelumnya yang mana penurunan yang megalami penurunan yang signifikan.

\section{Dampak Kredit Bermasalah Terhadap Pendapatan Profitabilitas Pada Bank Perkreditan Rakyat (BPR) KCP Limbanang}

Berikut ini data kredit bermasalah pada Bank Perkreditan Rakyat (BPR) KCP Limbanang pada tahun 2011 sampai 2015 :

Tabel 3

Kredit Bermasalah pada Bank Perkreditan Rakyat (BPR) KCP Limbanang

\begin{tabular}{|c|c|}
\hline Tahun & $\begin{array}{c}\text { Persentase Kredit Bermasalah } \\
\text { \% }\end{array}$ \\
\hline 2011 & $1.60 \%$ \\
\hline 2012 & $0.48 \%$ \\
\hline 2013 & $0.70 \%$ \\
\hline 2014 & $0.90 \%$ \\
\hline 2015 & $0.61 \%$ \\
\hline
\end{tabular}

(Sumber : Bank Perkreditan Rakyat (BPR) KCP Limbanang)

Pada tabel diatas tersebut kredit bermasalah yang terjadi pada tahun 2011 persentase kredit bermasalah sebesar $1.60 \%$ maka kredit bermasalahnya tidak berdampak pada pendapatan profitabilitas Bank Perkreditan Rakyat (BPR) KCP Limbanang, begitu juga untuk tahun 2012 sebesar $0.48 \%, 2013$ sebesar $0.70 \%$, 2014 sebesar $0.90 \%$ dan pada tahun 2015 sebesar $0.61 \%$ mengalami penurunan kredit bermasalah artinya perkembangan kredit bermasalah yang ada pada Perkreditan Rakyat (BPR) KCP Limbanang tidaklah berdampak pada pendapatan profitabilitas, karena persentase kredit bermasalah yang terdapat setiap tahunnya kurang dari $5 \%$ bahkan setiap tahunnya mengalami penurunan pada kredit bermasalah.

Dampak Tingkat Suku Bunga Terhadap Pendapatan Profitabilitas Pada Perkreditan Rakyat (BPR) KCP Limbanang 
Tabel 4

Data ROA Bank Perkreditan Rakyat (BPR) KCP Limbanang

\begin{tabular}{|c|c|}
\hline Tahun & Hasil \\
\hline 2011 & $2.44 \%$ \\
\hline 2012 & $1.73 \%$ \\
\hline 2013 & $6.74 \%$ \\
\hline 2014 & $7.80 \%$ \\
\hline 2015 & $2.13 \%$ \\
\hline
\end{tabular}

(Sumber : Bank Perkreditan Rakyat (BPR) KCP Limbanang)

Dari hasil perhitungan ROA diatas dapat kita ketahui persentase profitabilititas dengan menggunakan rumus ROA yang ada pada Bank Perkreditan Rakyat (BPR) KCP Limbanang pada tahun 2011 sampai 2015, yang mana setiap tahunnya persentase profitabilitas Bank Perkreditan Rakyat (BPR) KCP Limbanang mengalami fluktuasi.

\section{KESIMPULAN}

Berdasarkan hasil penelitian pada PT. Bank Perkreditan Rakyat (BPR) KCP Limbanang Kabupaten Lima Puluh Kota, maka dapat ditarik kesimpulan sebagai berikut :

1. Tingkat kredit bermasalah yang terjadi pada Bank Perkreditan Rakyat (BPR) KCP Limbanang Kabupaten Lima Puluh Kota dari tahun 2011-2012 tingkat kredit bermasalah mengalami penurunan dibandingkan tahun sebelumnya sebesar, itu berarti keadaan kredit semakin membaik. Hal tersebut disebabkan oleh kecenderungan positif tentang membaiknya perekonomian Indonesia yang ditandai dengan semakin lancarnya para debitur dalam membayar utangutangnya sehingga jumlah kredit bermasalah menurun.

2. Tingkat kredit bermasalah yang terjadi pada Bank Perkreditan Rakyat (BPR) KCP Limbanang Kabupaten Lima Puluh Kota dari tahun 2013-2014 tingkat kredit bermasalah mengalami kenaikan setiap tahunnya yang mana pada tahun 2013 pada tahun 2014 mengalami kenaikan kembali, itu berarti keadaan kredit mengalami keburukan. Hal ini disebabkan karena pihak debitur tidak mampu dalam melunasi utang kreditnya tersebut. Pada tahun 2015 kredit bermasalah mengalami penurunan.

3. Tingkat suku bunga yang terjadi pada Bank Perkreditan Rakyat (BPR) KCP Limbanang Kabupaten Lima Puluh Kota pada tahun 2011-2015 mengalami fluktuasi buktinya tingkat suku bunga tertinggi pada tahun 2011 dan tingkat suku bunga terendah yaitu pada tahun 2015 .

4. Tingkat suku bunga yang terjadi pada Bank Perkreditan Rakyat (BPR) KCP Limbanang Kabupaten Lima Puluh Kota karena setiap tahun mengalami penurunan maka ini akan mempengaruhi dalam penyaluran kredit, dimana semakin turunnya tingkat suku bunga pada suatu bunga maka jumlah kredit yang disalurkan akan meningkat pada bank tersebut.

5. Profiabilitas yang ada pada Bank Perkreditan Rakyat (BPR) KCP Limbanang Kabupaten Lima Puluh Kota dapat dilihat dengan setiap tahunnya profitabilitas setiap tahunnya mengalami fluktuatif, ini karena laba setelah pajak yang juga mengalami penurunan yang akan menyebabkan turunnya profitabilitas terbukti pada tahun 2011-2012 laba setelah pajak mengalami penurunan dan mengakibatkan juga profitabilitas turun.

6. Karena total aset pada Bank Perkreditan Rakyat (BPR) KCP Limbanang Kabupaten Lima Puluh Kota tersebut setiap tahunnya mengalami peningkatan yang signifikan sedangkan profitabilitas dari tahun 2011-2015 yang mengalami naik turunnya profitabilitas tersebut, hal ini dipengaruhi 
Jurnal EKOBISTEK Fakultas Ekonomi , Vol. 7, No. 1, April 2018, Hal 26-33 ISSN : 2301-5268 | E-ISSN : 2527-9483 Copyright@2018 by LPPM UPI YPTK Padang

oleh adanya penataan kembali syarat dan ketentuan kredit Bank Mandiri Kcp Simpang Empat Pasaman Barat.

\section{Daftar Pustaka}

[1] Aakesa, Ade. 2006. Bank dan Lembaga Keuangan Bank. Jakarta : PT. Indexs kelompok Gramedia.

[2] Abdullah, Thamrin. Francis Tantri 2014. Bank dan Lembaga Keuangan Lainnya. Jakarta : PT Raja Grafindo Persada.

[3] Budisantoso, Totok. Nuritomo. 2015. Bank dan Lembaga Keuangan lain. Jakarta : Salemba Empat

[4] Fahmi, Irham. 2014. Bank dan Lembaga Keuangan Lainnya. Bandung : Alfabeta.

[5] Fahmi, Irham. 2014. Manajemen Perkreditan. Bandung : Alfabeta.

[6] Hariyani, Iswi. 2010. Restrukturisasi dan Penghapusan Kredit Macet. Jakarta : PT. Elex Media Komputindo.

[7] Jayanti, Andi. 2012. Perlakuan Akuntansi Kredit Bermasalah (Nonperforming Loan) Kesesuaiannya Sebelum dan Sesudah Pernyataan Standar Akuntansi Keuangan No. 31 Efektif Dicabut Pada PT Bank Negara Indonesia (Persero) Tbk. Fakultas Ekonomi dan Bisnis, Universitas Hasanuddin.

[8] Kasmir. 2014. Bank dan Lembaga Keuangan Lainnya. Jakarta : PT Raja Grafindo Persada.

[9] Sanusi, Anwar. 2011, Metode Penelitian Bisnis, Jakarta : Salemba Empat. 